\title{
Özgün araştırma makalesi Bir grup Türk çocuk popülasyonunda sendroma bağlı olmayan oligodonti prevalansı
}

\author{
Canan Bayraktar iD, ${ }^{1 *}$ Zuhal Kırzıoğlu iD ${ }^{2}$ \\ ${ }^{1}$ Pedodonti Anabilim Dalı, Diş Hekimliği Fakültesi, Kütahya \\ Sağlık Bilimleri Üniversitesi, Kütahya, ${ }^{2}$ Pedodonti Anabilim \\ Dalı, Diş Hekimliği Fakültesi, Süleyman Demirel Üniversitesi, \\ Isparta, Türkiye
}

\section{Özet}

AmAÇ: Bu çalışmanın amacı, Isparta ve çevresinde yaşayan Türk çocuklarında oligodontinin prevalansı ve dağılımını belirlemektir.

Gereç ve Yöntem: Süleyman Demirel Üniversitesi Diş Hekimliği Fakültesi, Pedodonti Anabilim Dalına 1999-2018 yılları arasında başvuran ve oligodonti tanısı konulmuş hasta kayıtları tarandı. Herhangi bir sistemik rahatsızı̆̆ı olmayan, üçüncü büyük azı dişleri hariç 6 ve daha fazla dişi eksik olan 6-18 yaş aralığında 112 birey çalışmaya dahil edildi. Saptanan diş eksikliklerinin, eksik diş sayılarına, dişlere, cinsiyete ve çenelere göre dağılımı ve diş eksikliği paternleri incelendi. Diş eksikliği görülme sıklığı sayı ve yüzde olarak tablolanıp, cinsiyet ve eksik dişlerin çenelere göre dağılımında Mann-Whitney U testi uygulandı. Diş eksikliği paternlerini belirlemek için Tooth Agenesis Code/Diş Eksikliği Kodu (TAC) değerleri verilerine frekans analizi yapıldı.

BULGULAR: Çalışmamızda Isparta ve çevresinde yaşayan Türk çocuklarında, sendroma bağlı olmayan oligodontinin görülme sıklığı \%0.08 oranında saptandı. Birey başına düşen konjenital eksik diş sayısı 9.05 olarak bulundu ve eksikliği en sık görülen dişler, alt ve üst 2. küçük azı dişleri olarak gözlendi. Diş eksikliği cinsiyetler ve çeneler arasında karşılaştırıldığında aradaki farklar istatistiksel olarak anlamlı bulunmadı. Yaygın izlenen eksik diş paternleri, üst çenede küçük azı ve lateral kesici kombinasyonu iken, alt çenede küçük azı dişleri ve lateral kesici dişlerin kombinasyonu şeklinde oldu.

Sonuç: Elde edilen sonuçlar dahilinde, Isparta ve çevresinde her on bin çocuktan 8'inde oligodonti varlığı tespit edildi. Oligodontinin erken teşhisi ile birlikte, şiddeti ve dağılımı göz önüne alınarak uygulanabilecek alternatif tedaviler önemli olabilir.

Makale gönderiliș tarihi:13 Kasım 2019; Yayına kabul tarihi: 21 Haziran 2020 *iletişim: Dr. Canan Bayraktar, Kütahya Sağlık Bilimleri Üniversitesi,

Diş Hekimliği Fakültesi, Pedodonti Anabilim Dalı, 43100, Kütahya, Türkiye

E-posta: canannbayraktarr@gmail.com
Anahtar Kelimeler: Çocuk diş hekimliği; diş eksikliği; epidemiyoloji

Kaynak Göstermek İçin: Bayraktar C, Kırzıoğlu Z. Bir grup Türk çocuk popülasyonunda sendroma bağlı olmayan oligodonti prevalansı. Acta Odontol Turc 2021;38(1):8-13 Editör: Neşe Akal, Gazi Üniversitesi, Ankara, Türkiye

YAYıN HAKKı: () 2021 Bayraktar ve Kırzıoğlu. Bu eserin yayın hakkı Creative Commons Attribution License ile ruhsatlandırılmışıı. Sınırsız kullanım, dağıtım ve her türlü ortamda çoğaltım, yazarlar ve kaynağın belirtilmesi kaydıyla serbesttir.

FinANSAL Destek: Bulunmamaktadır.

ÇıKAR ÇATıŞMASı: Bulunmamaktadır.

[The abstract in English is at the end of the manuscript]

Giriş

Konjenital diş eksikliği; hipodonti, oligodonti, diş agenezisi, diş aplazisi, diş yokluğu vb. gibi terminolojide karışıklığa neden olan terimleri içine alan ve sık görülen gelişimsel diş anomalilerinden biridir. Beş veya daha az olan daimi diş eksikliği hipodonti olarak adlandırılırken, altı veya daha fazla daimi dişin eksikliği oligodonti olarak tanımlanmaktadır. ${ }^{1}$

Coğrafik olarak oligodonti görülme sıklığının, farklı populasyonlarda değiştiği ve hipodontiye göre daha az sıklıkta olduğu bildirilmiştir. Amerika'da \%0.05-7.44, ${ }^{2,3}$ Avrupa'da \%0.08-8.93, ${ }^{4,5}$ ve Asya'da \%0.13-1.996-8 arasında oligodonti izlendiği bildirilmiştir. Ülkemizde yapılan çalışmalarda, hipodonti prevalansı \%2.637.95 arasında yer alırken ${ }^{6,9-14}$ oligodonti prevalansının $\%$ 0.07-0.71 arasında olduğu bildirilmiştir. ${ }^{6,9,11,14}$

Oligodontiyi doğru tespit edebilmek için klinik ve radyolojik muayenenin yanı sıra, hasta ve ebeveyninden ayrıntılı anamnez alarak hastaların eksik diş bölgelerinde süt dişi dışında herhangi bir diş çekimi yapılmamış olduğu da doğrulanmalıdır. ${ }^{15}$

Oligodontinin etiyolojisini inceleyen birçok çalışma yapılmasına rağmen, bu konu henüz tam olarak aydınlatılabilmiş değildir. Oligodontinin; genetik orijinden, çevresel faktörlerden ve dişin gelişim zamanından etkilenen multifaktöriyel bir durum olduğu düşünülmektedir. ${ }^{16}$ Genel faktörler, genetik ve 
Tablo 1. Oligodontili bireylerde birey başına düşen konjenital eksik diş sayısı

\begin{tabular}{llllll}
\hline & $\begin{array}{l}\text { Birey sayısı } \\
\mathbf{n}(\%)\end{array}$ & Yaş Ort \pm SD & $\begin{array}{l}\text { Toplam eksik } \\
\text { diş sayısı }\end{array}$ & $\begin{array}{l}\text { Birey başına düşen } \\
\text { eksik diş sayısı }\end{array}$ & Ortanca değer \\
\hline Kız değeri & $60(\% 53.60)$ & $12.92 \pm 3.16$ & 539 & 8.98 & 0.85 \\
Erkek & $52(\% 46.40)$ & $12.25 \pm 3.12$ & 475 & 9.13 & 8.00 \\
\hline Toplam & $112(\% 100)$ & $12.68 \pm 3.14$ & 1,014 & 9.05 & 8.00 \\
\hline
\end{tabular}

Ort: ortalama, SD: standart sapma

sendromlarla ilişkilendirilirken, lokal faktörler arasında radyasyon, metabolik ve hormonal bozukluklar, travma, osteomyelit ve süt dişi çekimi sırasında yanlışlıkla yapılan sürekli diş germi çekimi yer almaktadır. ${ }^{17}$

Az sayıdaki diş eksikliğinin prevalansı ve dağılımı ile ilgili pek çok çalışma yapılmasına rağmen, Türk çocuklarında sendroma bağlı olmayan oligodonti prevalansı ile ilgili yapılan çalışmalar az sayıda olup, veriler oldukça sınırlıdır., 6,9,11

$\mathrm{Bu}$ çalışmanın amacı, Isparta ve çevresinde yaşayan Türk çocuklarında oligodontinin prevalansı ve dağılımını belirlemektir.

\section{Gereç Ve Yöntem}

Çalışmanın etik kurul onayı, Süleyman Demirel Üniversitesi Tıp Fakültesi Klinik Araştırmalar Etik Kurul Başkanlığı'ndan alındı (18.04.2018 tarih ve 99 sayılı karar).

Süleyman Demirel Üniversitesi Diş Hekimliği Fakültesi, Pedodonti Anabilim Dalı'na 1999-2018 yılları arasında başvurup klinik ve radyografik olarak oligodonti tanısı konulmuş ve yazılı onamları alınmış 123 hastaya ait arşiv kayıtları tarandı.

$\mathrm{Bu}$ retrospektif çalışma için anabilim dalı hasta arşivinde oligodonti tanısı ile bulunan 123 hastanın panoramik radyografileri ve verdikleri anamnezler incelenerek oligodonti varlığı doğrulandı. Panoramik filmler, panoramik röntgen cihazı (Planmeca Oy, Helsinki, Finlandiya) ile elde edilip, Negatoskop (Illuminator 5000, RP Beard LTD, Londra, Birleşik Krallık) üzerinden veya bilgisayar film arşivinden (Enlil HBYS v4.0.1, Mergen Yazılım AŞ. Eskişehir, Türkiye) değerlendirildi.

Hasta seçiminde şu şartlar göz önünde bulunduruldu:

1. Herhangi bir sistemik rahatsızlığı ve sendromu bulunmaması,

2. Bireylerde diş eksikliğine sebep olabilecek konjenital herhangi bir anomali olmaması (dudak damak yarığı gibi),

3. Arşiv kayıtları ve anamnezlerin eksiksiz doldurulmuş ve panoramik radyografilerin teşhis için yeterli kalitede olması

4. Daimi 3. büyük azı dişler hariç altı ve daha fazla dişin eksik olması

5. Bireylerin eksik diş bölgelerinde süt dişi dışında herhangi bir diş çekimi yapılmamış olması,

6. Diş eksikliğine sebep olacak çekim, travma, çürük, periodontal rahatsızlık gibi etkeni olan bireylerin olmaması.

Tüm bu kriterler doğrultusunda 123 birey tarandı ve $60 \mathrm{kız}$ (\%53.6) (12.92 \pm 3.16 yaş) ve 52 erkekten (\%46.4) (12.25 \pm 3.12 yaş) oluşan 112 bireyin $(12.68 \pm 3.14$ yaş) yukarıdaki kriterlere uygun olduğu saptanıp çalışmaya dahil edildi.

Saptanan diş eksikliklerinin, eksik diş sayılarına, dişlere, cinsiyete ve çenelere göre dağılımı incelendi. En sık görülen diş eksikliği paternlerini tanımlamak için Tooth Agenesis Code/Diş Eksikliği Kodu (TAC) prosedürü kullanıldı. ${ }^{18}$ Dişlerin varlığı ve yokluğunu ifade etmek için 1 ve 0 rakamları kullanılarak, her diş kadranında eksik dişler için karşılık gelen sayı değerleri oluşturuldu. $n=e k s i k$ dişin numarası olmak üzere, her bir eksik diş için 'dişin değeri', $2^{(n-1)}$ formülüyle hesaplandı. Örneğin, lateral kesici diş ve 1. küçük azı dişi eksik olan bir bireyin o kadrandaki TAC değeri $2^{(2-1)}$ $+2^{(4-1)}=10$ 'dur. Bu şekilde her diş kadranı ayrı ayrı analiz edilerek diş eksikliği paternlerini belirleyen TAC değerleri hesaplandı. ${ }^{18}$

Çalışmaya başlamadan önce, rastgele seçilmiş 20 radyografi, farklı zaman aralıklarında, 2 defa değerlendirilip araştırmacının kendi içinde olan uyumu için, Intraclass Correlation Coefficient (ICC) değeri hesaplandı.

\section{İstatistiksel analiz}

İstatistiksel değerlendirme, SPSS v23 (Chicago, IL, $A B D)$ yazılım paket programı kullanılarak yapıldı. Diş eksikliği görülme sıklığı bakımından elde edilen veriler sayı ve yüzde olarak özetlendikten sonra, cinsiyet ve eksik dişlerin çenelere göre dağılımı Mann-Whitney $U$ testi uygulanarak tablolar oluşturuldu. En sık izlenen diş eksikliği paternlerini belirlemek için TAC değerlerinden oluşan verilere frekans analizi yapıldı. Tüm testlerde $\mathrm{p}<0.05$ istatistiksel olarak anlamlı kabul edildi.

\section{BULGULAR}

Araştırmacının kendi içindeki tutarlılığının değerlendirilmesi için belirlenen ICC değeri 0.92 olarak saptanıp elde edilen değerin, ölçümler arasında istatistiksel olarak anlamlı bir fark yaratmadığı görüldü.

Kliniğimize 1999-2018 yılları arasında giriş yapmış olan 141,800 hastadan 112'sine sendroma bağlı 
Tablo 2. Oligodontili bireylerde diş eksikliği görülme sıklığı

\begin{tabular}{lllllllllllllll}
\hline Diş no & $\mathbf{1 7}$ & $\mathbf{1 6}$ & $\mathbf{1 5}$ & $\mathbf{1 4}$ & $\mathbf{1 3}$ & $\mathbf{1 2}$ & $\mathbf{1 1}$ & $\mathbf{2 1}$ & $\mathbf{2 2}$ & $\mathbf{2 3}$ & $\mathbf{2 4}$ & $\mathbf{2 5}$ & $\mathbf{2 6}$ & $\mathbf{2 7}$ \\
\hline Eksik diş sayısı & 30 & 15 & 76 & 50 & 23 & 68 & $\mathbf{1}$ & $\mathbf{1}$ & 66 & 29 & 45 & 79 & 14 & 33 \\
$\%$ & 3.0 & 1.5 & 7.5 & 4.9 & 2.3 & 6.7 & 0.1 & 0.1 & 6.5 & 2.9 & 4.4 & 7.8 & 1.4 & 3.3 \\
\hline Diş no & $\mathbf{4 7}$ & $\mathbf{4 6}$ & $\mathbf{4 5}$ & $\mathbf{4 4}$ & $\mathbf{4 3}$ & $\mathbf{4 2}$ & $\mathbf{4 1}$ & $\mathbf{3 1}$ & $\mathbf{3 2}$ & $\mathbf{3 3}$ & $\mathbf{3 4}$ & $\mathbf{3 5}$ & $\mathbf{3 6}$ & $\mathbf{3 7}$ \\
\hline Eksik diş sayısı & 40 & 12 & 79 & 21 & 10 & 25 & 52 & 52 & 27 & 10 & 25 & 88 & 11 & 32 \\
$\%$ & 3.9 & 1.2 & 7.8 & 2.1 & 1.0 & 2.5 & 5.1 & 5.1 & 2.7 & 1.0 & 2.5 & 8.7 & 1.1 & 3.2 \\
\hline
\end{tabular}

olmayan oligodonti tanısı konuldu. Çalışmamızda Isparta ve çevresinde yaşayan Türk çocuklarında, sendroma bağlı olmayan oligodontinin görülme sıklığı $\% 0.08$ oranında saptandı.

Çalışma grubumuz, diş eksikliğine rastlanan 60 kız (\%53.6) (12.92 \pm 3.16 yaş) ve 52 erkek (\%46.4) (12.25 \pm 3.12 yaş) hastadan oluşturuldu. 112 bireyde (12.68 \pm 3.14 yaş) toplam 1,014 eksik diş görüldü ve birey başına düşen konjenital eksik diş sayısı 9.05 olarak saptandı. Bu rakam kızlarda 8.98; erkeklerde ise 9.13 olarak izlendi, kız ve erkekler arasındaki fark istatistiksel olarak anlamlı bulunmadı $(p=0.85)$ (Tablo 1).

Oligodontili bireylerin eksik diş sayısına göre dağılımı belirtildi ve diş eksikliği sayısı sıklıkla 6-10 diş eksikliği olarak izlendi (Şekil 1).

Daimi üçüncü büyük azı dişler hariç olmak şartıyla, eksikliği en sık görülen dişler sırasıyla, alt 2. küçük azı, üst 2. küçük azı ve üst lateral kesici dişler iken, eksikliği en az görülen dişlerin ise üst santral kesici dişlerin ardından, alt kanin ve alt 1 . büyük azı olarak izlendi (Tablo 2).

Tablo 3'te, cinsiyete, üst/alt çeneye ve çenelerdeki sağ/sol tarafa göre diş eksiklikleri sunuldu. Diş eksikliği kızlarda (\%53.1) erkeklerden (\%46.9) daha fazla izlenip, aradaki fark istatistiksel olarak anlamlı bulunmadı $(p>0.05)$. Çeneler arasındaki eksik diş sayısı değerlendirildiğinde üst çenede (\%52.3), alt çeneye (\%47.7) göre daha fazla eksik dişin bulunduğu ve bu farkın istatistiksel olarak anlamlı olmadığı izlendi ( $p>0.05)$ Çenelerin sağ ve sol bölgelerindeki diş eksikliği sayısı incelendiğinde sol taraftaki (\%50.5) diş eksikliğinin, sağ taraftan (\%49.5) daha fazla olduğu, fakat aradaki farkın istatistiksel olarak anlamlı olmadığı görüldü ( $p>0.05)$.
Tablo 4'te, üst ve alt çenede her bir kadranda en sık görülen diş eksikliği paternleri sunuldu (Şekil 1). Üst çenenin sağ kadranında, 34 farklı diş eksikliği paterni izlenirken, en sık üst 1. ve 2. küçük azı dişlerin birlikte bulunmadığı $(\% 12.5)(T A C=24)$ görüldü. Üst çenenin sol kadranında, 31 farklı diş eksikliği paterninden en sık karşılaşılan paternin, üst lateral kesici diş ve üst 2. küçük azı dişinin birlikte bulunmadığı (\%11.6) (TAC=18) durum olduğu izlendi. Alt çenenin sağ kadranında 32 farklı diş eksikliği paterninden, en sık alt 2. küçük azının tek başına eksikliği izlenirken (\%18.8) (TAC=16), ikinci olarak alt 1. ve 2. küçük azı dişlerinin birlikte eksikliği (\%7.1) (TAC=24) görüldü. Alt çenenin sol kadranında 35 farklı diş eksikliği paterni izlenirken, en sık alt 2. küçük azının tek başına eksikliğine (\%19.6) (TAC=16), ardından alt lateral kesici ve alt 2. küçük azı dişlerinin bir arada eksikliğine (\%8.9) $(\mathrm{TAC}=17)$ rastlanıldı.

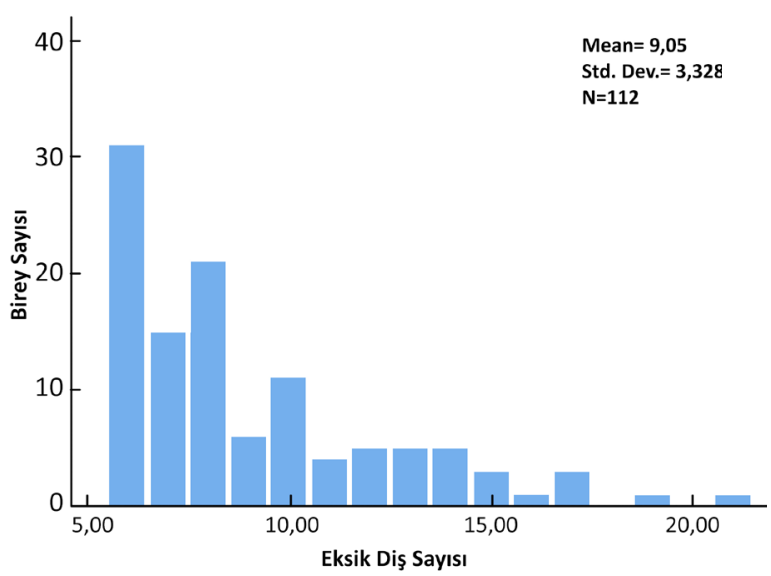

Şekil 1. Oligodontili bireylerin eksik dişs sayııına göre dağııımı

Tablo 3. Oligodontili bireylerde cinsiyete göre üst/alt çene ve sağ/sol bölge diş eksiklikleri

\begin{tabular}{|c|c|c|c|c|c|c|c|c|}
\hline \multicolumn{2}{|c|}{ Eksik diş sayısı } & \multicolumn{2}{|l|}{$\mathbf{K} \mathbf{z}$} & \multicolumn{2}{|c|}{ Erkek } & \multicolumn{2}{|c|}{ Toplam } & \multirow[t]{2}{*}{ P değeri } \\
\hline & & $\mathbf{n}$ & $\%$ & $\mathbf{n}$ & $\%$ & $\mathbf{n}$ & $\%$ & \\
\hline \multirow[t]{2}{*}{ Bölge } & Sağ & 271 & 54.0 & 231 & 46.0 & 502 & 49.5 & $>0.05$ \\
\hline & Sol & 268 & 52.3 & 244 & 47.7 & 512 & 50.5 & \\
\hline \multirow[t]{2}{*}{ Çene } & Üst & 290 & 54.7 & 240 & 45.3 & 530 & 52.3 & $>0.05$ \\
\hline & Alt & 249 & 51.4 & 235 & 48.6 & 484 & 47.7 & \\
\hline Toplam & & 539 & 53.1 & 475 & 46.9 & 1,014 & 100.0 & $>0.05$ \\
\hline
\end{tabular}


Tablo 4. Üst ve alt çenedeki her bir kadranda en sık görülen diş eksikliği paternleri

\begin{tabular}{llllllllllll}
\hline $\begin{array}{l}\text { Üst çene } \\
\text { Sağ }\end{array}$ & \multicolumn{9}{c}{ Sol } & \multicolumn{9}{c}{$\begin{array}{l}\text { Alt çene } \\
\text { Sağ }\end{array}$} \\
\hline TAC & $\begin{array}{l}\text { Eksik } \\
\text { dişler }\end{array}$ & $\%$ & TAC & $\begin{array}{l}\text { Eksik } \\
\text { dişler }\end{array}$ & $\%$ & TAC & $\begin{array}{l}\text { Eksik } \\
\text { dişler }\end{array}$ & $\%$ & TAC & $\begin{array}{l}\text { Eksik } \\
\text { dişler }\end{array}$ & $\%$ \\
\hline 24 & 14,15 & 12.5 & 18 & 22,25 & 11.6 & 16 & 45 & 18.8 & 16 & 35 & 19.6 \\
2 & 12 & 11.6 & 24 & 24,25 & 10.7 & 24 & 44,45 & 7.1 & 17 & 32,35 & 8.9 \\
18 & 12,15 & 8.9 & 2 & 22 & 10.7 & 80 & 45,47 & 6.3 & 24 & 34,35 & 7.1 \\
\hline
\end{tabular}

TAC: Diş eksikliği kodu. Daimi üçüncü büyük azı dişler dahil edilmemiştir.

\section{TARTIŞMA}

Konjenital diş eksikliği insanlarda en sık gözlenen dental anomalilerden biri olup, günümüze kadar çok sayıda konjenital diş eksikliğinin prevalans araştırmaları yapılmıştır. Ancak diş eksikliklerinin çok olduğu oligodonti olgularıyla ilgili çalışma sayısı oldukça sınırlıdır. Örneklem sayısının fazla olması, insidans/prevalans çaış̧malarının güvenilirliğini arttırmaktadır. ${ }^{19}$ Çalışmaların çoğunda, oligodontili bireylerde diş eksikliği sayısının, 6-10 diş arasında olduğu vurgulanırken, ${ }^{2,5,9,20,21}$ bunu belirtmeyen araştırmacılar da bulunmaktadır.,22,23 ÇaIışmamızda, örneklem sayısı benzer çalışmalara göre daha fazla olup, 112 oligodontili birey incelenmiştir. Bu bireylerin, 6-21 diş eksikliğini içeren geniş yelpazeli bir popülasyon oluşturmasının, sonuçların güvenilirliği açısından önemli olduğu düşünülmektedir.

Oligodontili bireylerde, diş eksikliği görülme sıklığının sunulduğu çalışmalarda, birey başına düşen eksik diş sayıları farklılık göstermektedir. Çalışma grubunun 2-15 birey ile sınırlı olduğu çalışmalarda, birey başına düşen eksik diş sayısı 6.9-12 arasında bildirilirken ${ }^{26}$, 228 bireyin dahil edildiği çalışmalarda birey başına 8.2-15.8 eksik dişin izlendiği bildirilmiştir. ${ }^{2,5,6,9,21-28}$ ÇaIışmamızda ise oligodontiye sahip toplamda 112 birey bulunması nedeniyle, birey başına düşen eksik diş sayısı 9.05 olarak hesaplanmıştır. Bununla birlikte 6-10 diş eksikliği bulunan 84 bireye bakıldığında birey başına düşen eksik diş sayısı 7.4 iken; 10 dişten daha fazla eksik dişi bulunan 28 bireyde ise bu sayı 14 olarak izlenmiştir. Örneklem sayısının değişmesiyle birey başına düşen eksik diş sayısının da değişkenlik gösterdiği düşülmektedir.

Oligodonti görülme sıklığı cinsiyetler arasında değerlendirildiğinde çalışmamızda, kızlarda diş eksikliği görülme sıklığı daha yüksek olup, istatistiksel olarak farkın önemli olmadığı saptanmıştır. Yapılan çalışmaların çoğunda, oligodonti görülme sıklığının kızlarda daha çok izlendiği bildirilirken, 2,5,11,20,21,24,27,29 cinsiyetler arasında herhangi bir farklılık olmadığını bildiren çalışmalar da mevcuttur.7,9,23,25

Günümüze kadar yapılan çalışmaların birçoğunda, eksikliğine en çok rastlanılan dişlerin alt 2. küçük azı dişler olduğu bildirilmiştir., 5,9,21,23,25-28 Bu dişleri sırasıyla üst lateral kesici ve üst 2 . küçük azı ${ }^{5,9,21,25-27}$ ya da üst 2. küçük azı ve üst lateral kesici dişlerin ${ }^{23}$ takip ettiğini bildiren çalışmalar mevcuttur. Bazı araştırmacılar ise eksikliği en sık izlenen dişlerin üst lateral kesici'711,22 ya da üst 2. küçük azı dişler olduğunu ${ }^{24}$ ve bu dişleri takiben alt 2. küçük azı ve alt santral kesici dişlerin izlendiğini bildirmişlerdir. Çalışmamızda da, eksikliği en sık izlenen diş alt çenede 2. küçük azı dişi olmuş ve bu dişi sırasıyla üst 2. küçük azı ve üst lateral kesici dişler izlemiştir. Garn ve arkadaşları ${ }^{30}$ eksikliği en sık görülen dişlerin, bir diş dizisinin en distalindeki diş olduğunu ileri sürmüşlerdir. Kesici dişler bölgesinde lateral kesicilerin, küçük azı dişleri bölgesinde 2. küçük azıların ve büyük azılar bölgesinde ise 3 . büyük azı dişlerin eksikliğinin sıklıkla görülmesiyle, bu teorinin kanıtlandığı düşünülmektedir. Benzer şekilde memeli diş gelişimi alan teorisinde de, her bir diş grubunda distaldeki dişin eksikliği, boyut değişikliği ve gelişim geriliği gibi anomalilere sahip olabileceği bildirilmekle beraber, niçin en distaldeki dişlerin etkilendiği konusu belirsizliğini korumaktadır. ${ }^{31}$

Diş eksikliğinin, her bir diş dizisindeki distal dişleri etkilemesinin yanı sıra çeneler arasındaki dağılımının belirlenmesinin de etiyolojiye katkıda bulunabileceği düşünülmektedir. Diş eksikliklerinin alt ya da üst çeneden hangisinde daha çok izlendiği araştırılmış ve farklı sonuçlar elde edilmiştir. Bazı araştırmacılar, diş eksikliğinin üst çenede daha sık izlendiğini bildirirken,,211,27 alt çenede daha sık rastlandığını belirten araştırıcılar da mevcuttur. ${ }^{21}$ Araştırmacılardan bazılarının yaptığı meta-analiz çalışmasında ise, her iki çenede de benzer oranda diş eksikliği gözlendiği belirtilmiş ve farklılığın dişin tipine göre değişiklik gösterebileceği bildirilmiştir. ${ }^{20}$ Çalışmamızda diş eksikliği görülme sıklığı üst çenede daha çok görülmüş, ancak istatistiksel olarak anlamlı bulunmamıştır. Kær ${ }^{32}$ alt ve üst çenede farklı oranlarda diş eksikliği oluşma sebebini, nöral gelişim ile açıklamaktadır. Alt çenenin sinirsel iletimi inferior alveolar sinir ile sağlanırken, üst çenede palatinal, nazopalatin ve infraorbital sinir dalları bulunduğunu, inferior alveolar sinirin, mandibulanın kompakt yapısı sayesinde daha korunaklıyken, üst çenede yer alan sinir dallarının daha yüzeyel ve geniş alanda seyretmesi, bu bölgede sinir hasarlarının daha çok olduğunu belirtmiştir. Çenelerin inervasyonunu sağlayan bu sinirlerde oluşan bir hasar, diş eksikliği ile ilişkilendirilmekte olup, diş eksikliğinin sinir uzantılarına uzak bölgelerde oluşabileceği belirtilirken, mekanizması açıklanmamıştır. ${ }^{32}$

Kær'in ${ }^{32}$ nöral gelişim teorisi alt ve üst çenedeki diş eksikliklerinin sebebini açıklarken, çenelerin sağ ve sol 
tarafındaki diş eksiklikleri arasında fark olup olmadığını açıklamada yetersiz kalmaktadır. Çalışmalara bakıldığında, çenenin sağ ve sol tarafında diş eksikliği görülme sıklığı arasında istatistiksel olarak anlamlı bir fark izlenmediği bildirilirken, ${ }^{3,9,11}$ sağ tarafta daha sık izlendiğini belirten çalışmalar da mevcuttur. . $^{2,33}$ Çalışmamızda, diş eksikliği sayısal olarak çenenin sol tarafında fazla olsa da, istatistiksel olarak anlamlı bir farklılık izlenmemiştir. Hua ve arkadaşlarının ${ }^{34}$ yaptıkları meta analiz çalışmasında, diş eksikliklerinin ve atipik formdaki dişlerin sol tarafta daha sık izlendiğini bildirmişlerdir. Araştırmacılar, Gundlach ve Maus'un ${ }^{35}$ dudak damak yarıklarının hangi tarafta daha sık görüldüğü ile ilgili çalışmasını kaynak göstererek, sol taraftaki diş eksikliklerinin dudak damak yarıklarıyla benzer genetik mekanizmaya sahip olabileceklerini ileri sürmüşlerdir. Bu bağlamda çalışmamızdaki bu bulgunun da tesadüfi mi yoksa benzer bir mekanizmaya mı dayalı olduğu merak konusu olmaktadır.

Çalışmamızda yaygın diş eksikliği paternlerini belirleyebilmek için TAC prosedürü uygulanmıştır. ${ }^{18}$ Üçüncü büyük azı dişlerinin dahil edilmesi veya edilmemesi TAC prosedürünü etkilememektedir. Üçüncü büyük azı dişleri hariç tutulduğunda, TAC değerleri 0 ile 127 arasında yer almaktadır (128 TAC değeri). ${ }^{18}$ Çalışmamızda üçüncü büyük azı eksikliği tam olarak belirlenemediği için bu dişler çalışma dışı bırakılmıştır. Böylece yaygın izlenen diş eksikliği paternleri, üst çene için küçük azı dişleri ve lateral kesici dişler ile küçük azı dişlerinin birlikte eksikliğinin görülmesi iken, alt çenede küçük azı dişlerinin eksiklerine rastlamanın yanında bu dişlere eşlik eden lateral kesici diş ve 2. büyük azı dişleri de yer almaktadır. Yapılan benzer bir çalışmada ise, üst çenede yaygın olarak lateral kesici diş, köpek dişi ve her iki küçük azı dişlerinin eksikliğine rastlanırken, alt çenede tüm küçük azı dişlerinin eksikliği izlenmektedir. ${ }^{36}$ Diş eksikliğine, tek başına veya diğer genlerle kombine hareket edip belirli bir fenotipik paterne yol açan birkaç kusurlu gen neden olabilmektedir. ${ }^{37}$ Son zamanlarda, diş eksikliğinden sorumlu genler tanımlanmakta olup, MSX1 ve PAX9'daki mutasyonlar insanlarda diş agenezi ile ilişkilendirilmektedir. ${ }^{38}$ Literatürde MSX1 mutasyonlarının esas olarak küçük azı eksikliğine neden olurken, PAX9 mutasyonlarının ise büyük azı eksikliğine neden olabileceği ileri sürülmektedir. ${ }^{39}$ Şimdiye kadar, genetik mutasyonların spesifik diş eksikliği paterni ile nasıl ilişkili olduğu tam olarak bilinmemektedir. Gelecekteki genetik çalışmalarla birlikte klinik verilerin TAC analizi, hangi spesifik diş agenezi paternlerinin genetik mutasyonlarla ilişkili olup olmadığını gösterecektir.

Çalışmamızın eksik yönü, bireylerin sadece anamnez bilgileri dikkate alınarak seçim kriteri oluşturulması sebebiyle henüz teşhis edilmemiş bazı sistemik ve sendromik durumların gözden kaçırılarak çalışmaya dahil olabilmesi ve bazı bireylerde, özellikle premolar dişlerin, belirtilen yaş grubundan daha geç dönemde gelişmesi nedeniyle 6-8 yaşları arasındaki diş eksikliği teşhislerinin yanlış tanımlanma intimalidir.

\section{SonUÇ}

Elde edilen bulgulara göre, Isparta ve çevresinde her 10,000 çocuktan 8'inde oligodonti varlığı tespit edildi. Oligodonti gibi çok sayıdaki diş eksikliğinin şiddeti ve çenelerdeki dağılımı göz önüne alınarak erken tanı konulması, bu süreçte meydana gelebilecek ağız içi değişikliklerinin takip edilerek alternatif tedavi prosedürlerinin uygulanmasına olanak sağlayabilir.

\section{KAYNAKLAR}

1. Schalk-van der Weide $Y$, Beemer FA, Faber JA, Bosman F. Symptomatology of patients with oligodontia. $J$ Oral Rehabil 1994;21:247-61.

2. Muller TP, Hill IN, Petersen AC, Blayney JR. A survey of congenitally missing permanent teeth. J Am Dent Assoc 1970;81:101-7.

3. Maklin M, Dummett CO Jr, Weinberg R. A study of oligodontia in a sample of New Orleans children. ASDC J Dent Child 1979;46:478-82.

4. Nordgarden $\mathrm{H}$, Jensen JL, Storhaug K. Reported prevalence of congenitally missing teeth in two Norwegian counties. Community Dent Health 2002;19:258-61.

5. Gkantidis N, Katib H, Oeschger E, Karamolegkou M, Topouzelis N, Kanavakis $\mathrm{G}$. Patterns of non-syndromic permanent tooth agenesis in a large orthodontic population. Arch Oral Biol 2017;79:42-7.

6. Altug-Atac AT, Erdem D. Prevalence and distribution of dental anomalies in orthodontic patients. Am J Orthod Dentofacial Orthop 2007;131:510-4

7. Gupta SK, Saxena P, Jain S, Jain D. Prevalence and distribution of selected developmental dental anomalies in an Indian population. J Oral Sci 2011;53:231-8.

8. Arai K. Tooth agenesis patterns in Japanese orthodontic patients with nonsyndromic oligodontia. Am J Orthod Dentofacial Orthop 2019;156:238-47.

9. Sen Tunc E, Koyuturk AE. Karadeniz bölgesi çocuklarında konjenital daimi diş eksikliği prevalansı. Atatürk Üniv Dis Hek Fak Derg 2006;16:37-40.

10. Sisman Y, Uysal T, Gelgor IE. Hypodontia. Does the prevalence and distribution pattern differ in orthodontic patients? Eur $\mathrm{J}$ Dent 2007;1:167-73.

11. Celikoglu M, Kazanci F, Miloglu O, Oztek O, Kamak H, Ceylan I. Frequency and characteristics of tooth agenesis among an orthodontic patient population. Med Oral Patol Oral Cir Bucal 2010;15:e797-801.

12. Gökkaya B, Motro $M$, Kargül B. Prevalence and characteristics of non-syndromic hypodontia among Turkish orthodontic patient population. J Int Soc Prev Community Dent 2015;5:170-5.

13. Gurbuz O, Ersen A, Dikmen B, Gumustas B, Gundogar M. The prevalence and distribution of the dental anomalies in the Turkish population. J Anat Soc India 2019;68:46-51.

14. Aktan AM, Kara IM, Sener I, Bereket C, Ay S, Ciftci ME. Radiographic study of tooth agenesis in the Turkish population. Oral Radiol 2010;26:95-100.

15. Kim YH. Investigation of hypodontia as clinically related dental anomaly: prevalence and characteristics. ISRN Dent 2011;2011:1-6.

16. Cobourne MT. Familial human hypodontia--is it all in the genes? $\mathrm{Br}$ Dent J 2007;203:203-8.

17. Nunn JH, Carter NE, Gillgrass TJ, Hobson RS, Jepson NJ, Meechan JG, et al. The interdisciplinary management of hypodontia: background and role of paediatric dentistry. Br Dent J 2003;194:245-51.

18. van Wijk AJ, Tan SP. A numeric code for identifying patterns of human tooth agenesis: a new approach. Eur J Oral Sci 2006;114:97-101.

19. Pearce N. Effect measures in prevalence studies. Environ Health Perspect 2004;112:1047-50.

20. Polder BJ, Van't Hof MA, Van der Linden FP, Kuijpers-Jagtman AM. A meta-analysis of the prevalence of dental agenesis of permanent 
teeth. Community Dent Oral Epidemiol 2004;32:217-26.

21. Rølling S, Poulsen S. Agenesis of permanent teeth in 8138 Danish schoolchildren: prevalence and intra-oral distribution according to gender. Int J Paediatr Dent 2009;19:172-5.

22. Shakra KA, Samer Alqaqaa D. Prevalence of hypodontia and oligodontia in a sample of orthodontic and pediatric dentistry patients at Prince Hashem bin Al-Hussein Military Hospital. J Royal Med Servic 2008;15:40-4

23. Țenț A, Todor L, Ciavoi G, Popovici-Mut AM, Domocoş D, Pogan $M D$, et al. Non-syndromic hypodontia of permanent dentition associated with other dental anomalies in children and adolescents. Rom J Morphol Embryol 2018;59:879-83.

24. Rølling S, Poulsen S. Oligodontia in Danish schoolchildren. Acta Odontol Scand 2001;59:111-2.

25. Behr M, Proff P, Leitzmann M, Pretzel M, Handel G, Schmalz G, et al. Survey of congenitally missing teeth in orthodontic patients in Eastern Bavaria. Eur J Orthod 2011;33:32-6.

26. Ceyhan D. Diş eksikliğine sahip çocuk ve genç bireylerin dişsel ve genetik özelliklerinin tanımlanması [doktora tezi]. Isparta: Süleyman Demirel Üniversitesi; 2010.

27. Gracco ALT, Zanatta S, Forin Valvecchi F, Bignotti D, Perri A, Baciliero F. Prevalence of dental agenesis in a sample of Italian orthodontic patients: an epidemiological study. Prog Orthod 2017;18:33

28. Sato A, Arai K. Estimation of tooth agenesis risks between tooth types in orthodontic patients with non-syndromic oligodontia. Orthod Waves 2019;78:49-55.

29. Mattheeuws N, Dermaut L, Martens G. Has hypodontia increased in Caucasians during the 20th century? A meta-analysis. Eur J Orthod 2004;26:99-103.

30. Garn SM, Lewis AB, Vicinus JH. Third molar polymorphism and its significance to dental genetics. J Dent Res 1963;42:1344-63.

31. Brook $\mathrm{AH}$. A unifying aetiological explanation for anomalies of human tooth number and size. Arch Oral Biol 1984;29:373-8.

32. Kær I. Can the location of tooth agenesis and the location of initial bone loss seen in juvenile periodontitis be explained by neural developmental fields in the jaws? Acta Odontol Scand 1997;55:70-2.

33. Pinho T, Tavares $P$, Maciel P, Pollmann C. Developmental absence of maxillary lateral incisors in the Portuguese population. Eur J Orthod 2005;27:443-9.

34. Hua F, He H, Ngan P, Bouzid W. Prevalence of peg-shaped maxillary permanent lateral incisors: A meta-analysis. Am J Orthod Dentofacial Orthop 2013;144:97-109.

35. Gundlach KK, Maus C. Epidemiological studies on the frequency of clefts in Europe and world-wide. J Craniomaxillofac Surg 2006;34:1-2.

36. Tan SP, van Wijk AJ, Prahl-Andersen B. Severe hypodontia: identifying patterns of human tooth agenesis. Eur $\mathrm{J}$ Orthod 2011;33:150-4.

37. Fournier BP, Bruneau MH, Toupenay S, Kerner S, Berdal A, Cormier-Daire $\mathrm{V}$, et al. Patterns of dental agenesis highlight the nature of the causative mutated genes. J Dent Res 2018;97:1306-16.
38. Vieira AR. Oral clefts and syndromic forms of tooth agenesis as models for genetics of isolated tooth agenesis. J Dent Res 2003;82:162-5.

39. Stockton DW, Das P, Goldenberg M, D'Souza RN, Patel PI. Mutation of PAX9 is associated with oligodontia. Nature Genetics 2000;24:18-9.

\section{Prevalence of non-syndrome-related oligodontia in a group of Turkish children}

\section{Abstract}

OBJECTIVE: This study aimed to determine the prevalence and distribution of non-syndrome-related oligodontia in Turkish children in Isparta and its surroundings.

Materials and Method: The records of patients who were admitted to the Department of Pedodontics, Faculty of Dentistry of Süleyman Demirel University between 19992018, and diagnosed with oligodontia were searched. One-hundred-twelve individuals between the ages of 6 and 18 who did not have any systemic disorders, and missing $\geq 6$ teeth except the third molars were included in the study. The distribution of detected tooth agenesis according to missing teeth, gender, and jaws and tooth agenesis patterns were examined. The frequency of tooth agenesis was given in numbers-percentages, and the Mann-Whitney $U$ test was applied to the distribution of gender and missing teeth. The frequency analysis was calculated using Tooth Agenesis Code (TAC) values to determine tooth agenesis patterns.

RESULTS: The incidence of non-syndrome-related oligodontia in Turkish children in Isparta and its surroundings was found to be $0.08 \%$. The number of missing teeth per individual was found to be 9.05 and the most commonly missing teeth were observed as lower/upper second premolars. When the tooth agenesis was compared between genders and jaws, the differences were not statistically significant. Commonly observed tooth agenesis patterns were a combination of premolars and lateral incisor.

Conclusion: According to the results, in Isparta and its surroundings, the presence of oligodontia was detected in 8 out of 10,000 children. Along with the early diagnosis, alternative treatment can be applied considering the severity and distribution of oligodontia.

KEYWORDS: Epidemiology; pediatric dentistry; tooth agenesis 